KOŚCIÓŁ I PRAWO 8(21) 2019, nr 1, s. 85-99

DOI: http://dx.doi.org/10.18290/kip.2019.8.1-6

\author{
Mirosław Sitarz
}

\title{
PRAWA DZIECKA W KODEKSIE PRAWA KANONICZNEGO Z 1983 ROKU. WYBRANE ZAGADNIENIA
}

Dziecko jest podmiotem praw zarówno w porządku państwowym, jak i kościelnym. Szczególna troska ustawodawcy o zagwarantowanie przysługujących każdemu dziecku uprawnień wynika z faktu, iż samo nie jest w stanie jeszcze skutecznie ich wyegzekwować. W celu scharakteryzowania wybranych praw dziecka skodyfikowanych w Kodeksie Prawa Kanonicznego z 1983 r. ${ }^{1}$ należy odpowiedzieć na następujące pytania: W jaki sposób ustawodawca kodeksowy definiuje pojęcie „dziecko”? Jaka jest podstawa jego osobowości prawnej w Kościele? Z jakim momentem dziecko nabywa określone uprawnienia w prawie kanonicznym? Czy wszystkie zagwarantowane dziecku uprawnienia wynikają z osobowości prawnej?

Ks. Dr Hab. MirosŁaw Sitarz, Prof. KUL - kierownik Katedry Kościelnego Prawa Publicznego i Konstytucyjnego, Instytut Prawa Kanonicznego, Wydział Prawa, Prawa Kanonicznego i Administracji Katolickiego Uniwersytetu Lubelskiego Jana Pawła II; adres do korespondencji: Al. Racławickie 14, 20-950 Lublin, Polska; e-mail: mpsitarz@kul.pl; https://orcid.org/0000-0001-7596-8508

${ }^{1}$ Codex Iuris Canonici auctoritate Ioannis Pauli PP. II promulgatus (25.01.1983), AAS 75 (1983), pars II, s. 1-317; tekst polski w: Kodeks Prawa Kanonicznego, przekład polski zatwierdzony przez Konferencję Episkopatu, Pallottinum, Poznań 1984 [dalej cyt.: KPK/83]. Poza analizą badawczą w niniejszym artykule pozostają m.in. takie akty normatywne, jak: Karta Praw Rodziny czy Konwencja o prawach dziecka. 


\section{POJĘCIE „DZIECKO” \\ W KODEKSIE PRAWA KANONICZNEGO \\ Z 1983 ROKU}

Wiek jest jednym z czynników determinujących pozycję kanoniczną osób fizycznych w Kościele, ponieważ implikuje zakres realizacji ich obowiązków i praw, tj. zdolność do czynności prawnych ${ }^{2}$. Ustawodawca kościelny - z punktu widzenia wieku - rozróżnia trzy kategorie osób: dziecko, małoletni i pełnoletni (kan. 97). Osoba, która ukończyła 18 lat określana jest jako „pełnoletni” (łac. maior), natomiast osoba poniżej lat 18 definiowana jest jako „małoletni” (łac. minor) ${ }^{3}$. W odniesieniu do określenia „dziecko” (łac. infans) ustawodawca w KPK/83 stanowi: „Małoletni, przed ukończeniem siódmego roku życia, nazywa się dzieckiem i uważany jest za nie posiadającego używania rozumu. Po skończonym siódmym roku życia domniemywa się, że posiada używanie rozumu" (kan. 97 §).

Dziecko jest osobą fizyczną przed ukończeniem siedmiu lat ${ }^{4}$. Ustawodawca kodeksowy wskazuje zatem górną temporalną granicę ${ }^{5}$, natomiast nie określa expressis verbis granicy dolnej. Brak jednoznacznej regulacji normatywnej w tym zakresie spowodował, że autorzy podejmujący analizę zagadnienia dziecka w prawie kanonicznym wyrażają dwa poglądy odnośnie do dolnej temporalnej granicy. Według pierwszego, dziecko to osoba od chwili urodzenia [Walesa 1983, 501], zaś według drugiego poglądu od momentu poczęcia [Wenz 2016, 152]. W związku z powyższym należy zadać pytanie: czy określenie dolnej temporalnej granicy dla pojęcia „dziecko" można wyprowadzić z ustawodawstwa kodeksowego? W celu udzielenia odpowiedzi trzeba w pierwszej kolejności sięgnąć do wyrażenia łacińskiego

\footnotetext{
${ }^{2}$ Nabycie osobowości prawnej w Kościele (zdolności prawnej) przez chrzest nie oznacza jeszcze możliwości pełnego realizowania obowiązków i uprawnień z tego wynikających [Pawluk 2002, 253].

${ }^{3}$ „Osoba, która ukończyła osiemnaście lat jest pełnoletnia; poniżej tego wieku małoletnia” (kan. 97 § 1).

${ }^{4}$ Wiek oblicza się według kan. $203 \S 2$ : „Jeżeli czegoś innego nie postanowiono, ostatni dzień wlicza się do terminu, który - jeśli czas obejmuje jeden lub więcej miesięcy albo lat, jeden lub kilka tygodni - kończy się po upływie ostatniego dnia tej samej daty, albo jeżeli miesiąc nie ma dnia o tej dacie, po upływie ostatniego dnia miesiąca".

${ }_{5}^{5}$ Zasada ta została przejęta od cesarza Justyniana I Wielkiego, zaś po raz pierwszy została wprowadzona do źródeł prawa kanonicznego w Dekretałach Grzegorza IX, które weszły w skład Corpus Iuris Canonici [Rybczyk 1983, 565].
} 
i jego tłumaczenia. Łaciński wyraz infans, -ntis został przełożony jako „dziecko”, a także „płód w łonie matki” [Plezia 2007, 136] ${ }^{6}$. Oznacza to, że osoba poczęta jest już dzieckiem. Za definiowaniem „dziecka” od momentu poczęcia przemawia także regulacja zawarta w Księdze VI KPK/83, w Tytule VI „Przestępstwa przeciwko życiu i wolności człowieka”, zgodnie z którą „Kto powoduje przerwanie ciąży, po zaistnieniu skutku, podlega ekskomunice wiążącej mocą samego prawa" (kan. 1398). Ustawodawca kościelny ochronie dziecka poczętego nadaje rangę normatywną. Ponadto, na podstawie kan. $19 \mathrm{w}$ zw. z kan. $22 \mathrm{KPK} / 83^{7}$, należy w tym przypadku uwzględnić również regulacje prawa państwowego. Zgodnie z ustawą o Rzeczniku Praw Dziecka "dzieckiem jest każda istota ludzka od poczęcia do osiągnięcia pełnoletności” (art. 2 ust. 1), natomiast Rzecznik Praw Dziecka zobowiązany jest do działania na rzecz ochrony praw dziecka, w szczególności „prawa do życia i ochrony zdrowia” (art. 3 ust. 2 pkt 1). „Taka regulacja jest unikatowa nie tylko z racji na nadanie wyjaśnieniu pojęcia rangi ustawowej, ale również ze względu na jednoznaczne przesądzenie jego dolnej temporalnej granicy" [Wiak 2017, 266].

Dziecko jest uważane za nieposiadające używania rozumu i jest niezdolne na płaszczyźnie prawnej do kierowania swoim postępowaniem (łac. non sui compos) [Sobański 2003, 167; Sitarz 2004, 46-47]. Nie jest zdolne do działań prawnych w Kościele, czyli nie posiada zdolności do czynności prawnych, dlatego $\mathrm{w}$ wykonywaniu swoich uprawnień podlega władzy rodziców lub opiekunów (kan. 98 § ) $^{9}$. Nie jest także zdolne do popełnienia

${ }^{6}$ Ponadto wyrażenie infans zostało przetłumaczone jako: niemy; jeszcze niemówiący; niemowlęcy; mały; niedorosły; młodziutki; dziecięcy; dziecinny; pozbawiony daru wymowy; niemądrze (jak dziecko) mówiący; zdziecinniały; niesłychany [Plezia, 2007, 135-36].

7 „Jeśli w określonej sprawie brak wyraźnej ustawy, powszechnej lub partykularnej, albo prawa zwyczajowego, sprawa - $\mathrm{z}$ wyjątkiem karnej - winna być rozstrzygnięta $\mathrm{z}$ uwzględnieniem ustaw wydanych $\mathrm{w}$ podobnych sprawach, ogólnych zasad prawnych z zachowaniem skuteczności kanonicznej, jurysprudencji, praktyki Kurii Rzymskiej oraz powszechnej i stałej opinii uczonych” (kan. 19); „Ustawy państwowe, do których odsyła prawo kościelne, należy zachować w prawie kanonicznym na ile nie są przeciwne prawu Bożemu i o ile prawo kanoniczne czego innego nie zastrzega" (kan. 22).

${ }^{8}$ Ustawa z dnia 6 stycznia 2000 r. o Rzeczniku Praw Dziecka, Dz. U. z 2017 r., poz. 922 z późn. zm.

9 „W wykonywaniu swoich uprawnień osoba małoletnia podlega władzy rodziców lub opiekunów, z wyjątkiem tych spraw, w których małoletni na podstawie prawa Bożego lub kanonicznego są wyjęci spod ich władzy; co do ustanowienia opiekunów oraz ich władzy, należy zachować przepisy prawa cywilnego, chyba że w prawie kanonicznym co innego 
przestępstwa (kan. $1323,1^{\circ}$ i $\left.6^{\circ}\right)^{10}$. Ponadto ustawodawca kodeksowy stanowi: „Ktokolwiek na stałe nie posiada używania rozumu, uznany jest za nieodpowiedzialnego i przyrównany dzieciom" (kan. 99). Dzieci nie podlegają „ustawom czysto kościelnym” (kan. 11) ${ }^{11}$.

Ustawodawca w KPK/83 podaje zasady określenia miejsca pochodzenia dziecka (kan. 101), jego zamieszkania (kan. 105) oraz przynależności do Kościoła (kan. 111-112) ${ }^{12}$. Ponadto reguluje kwestię skutków kanonicznych przysposobienia i legitymacji potomstwa. „Dzieci adoptowane zgodnie z przepisami prawa cywilnego uważane są za dzieci tego lub tych, którzy je adoptowali” (kan. 110). Adoptujący zrównani są w prawach i obowiązkach z rodzicami naturalnymi, zaś adoptowani z ich dziećmi. „Co do skutków

zastrzeżono albo biskup diecezjalny uznał w pewnych wypadkach, ze słusznej przyczyny, że należy zaradzić temu przez ustanowienie innego opiekuna” (kan. 98 §).

10 „Nie podlega żadnej karze, kto w chwili przekraczania ustawy lub nakazu: $1^{\circ}$ nie ukończył jeszcze szesnastego roku życia (..); $6^{\circ}$ nie posiadał używania rozumu z zachowaniem przepisów kan. 1324, § 1, n. 2 i 1325" (kan. 1323, $1^{\circ}$ i $6^{\circ}$ ).

11 „Ustawom czysto kościelnym podlegają ochrzczeni w Kościele katolickim lub do niego przyjęci, którzy jednak posiadają wystarczające używanie rozumu oraz - jeśli ustawa czego innego wyraźnie nie zastrzega - ukończyły siódmy rok życia” (kan. 11).

${ }^{12}$ Należy zauważyć, że kan. 111 i 112 KPK/83 zostały znowelizowane przez papieża Franciszka. Kan. 111: „§ 1. Do Kościoła łacińskiego zostaje włączone przez przyjęcie chrztu dziecko rodziców, którzy do niego należą, lub - jeśli jedno z nich do niego nie należy - którzy zgodnie sobie życzą, by potomstwo było ochrzczone w Kościele łacińskim. Jeżeli zaś brak zgodności, zostaje włączone do Kościoła sui iuris, do którego należy ojciec. $\S 2$. Jeżeli zaś tylko jedno z rodziców jest katolikiem, zostaje włączone do Kościoła, do którego należy rodzic, który jest katolikiem. § 3. Każdy z mających być ochrzczonym, który ukończył czternasty rok życia, może dobrowolnie wybrać chrzest w Kościele łacińskim lub w innym Kościele sui iuris; w takim wypadku należy do tego Kościoła, który wybrał”; kan. 112: „§ 1. Po przyjęciu chrztu, do innego Kościoła sui iuris zostają włączeni: $1^{\circ}$ ci, którzy otrzymali zezwolenie Stolicy Apostolskiej; $2^{\circ}$ małżonek, który zawierając małżeństwo lub w czasie jego trwania oświadczy, że pragnie przejść do Kościoła sui iuris swego małżonka; po rozwiązaniu jednak małżeństwa może w sposób nieskrępowany powrócić do Kościoła łacińskiego; $3^{\circ}$ dzieci tych, o których w nn. 1 i 2 , przed ukończeniem czternastego roku życia, a w małżeństwie mieszanym dzieci strony katolickiej, która zgodnie z przepisami prawa przeszła do innego Kościoła sui iuris; po osiągnięciu wskazanego wieku mogą powrócić do Kościoła łacińskiego. § 2. Nawet długotrwały zwyczaj przyjmowania sakramentów według obrzędów innego Kościoła sui iuris, nie pociąga za sobą przynależności do tego Kościoła. § 3. Każde przejście do innego Kościoła sui iuris osiąga skutek z chwilą złożenia oświadczenia wobec ordynariusza miejsca tego Kościoła albo wobec własnego proboszcza lub delegowanego przez jednego z nich kapłana i dwóch świadków, chyba że reskrypt Stolicy Apostolskiej stanowiłby inaczej; powinno być także odnotowane w księdze ochrzczonych", Franciscus PP., Litterae apostolicae motu proprio datae quibus nonnullae normae Codicis Iuris Canonici immutantur De concordia inter Codices (31.05.2016), AAS 108 (2016), s. 602-606, art. 1 i 2 [Romanko 2017, 146-50]. 
kanonicznych, dzieci, które uzyskały prawność pochodzenia, są zrównane we wszystkim z dziećmi prawego pochodzenia, chyba że prawo wyraźnie co innego zastrzega" (kan. 1140). Legitymacja potomstwa gwarantuje dziecku właściwe warunki do pełnego rozwoju w rodzinie [Pawluk 1996, 217].

\section{PRAWA DZIECKA}

Uprawnienia ${ }^{13}$ przysługujące dziecku mają podstawę zarówno w naturalnej osobowości prawnej, jak i w kościelnej osobowości prawnej. Naturalna osobowość prawna przysługuje każdej istocie ludzkiej od momentu poczęcia. Ma swoje źródło w prawie naturalnym (np. prawo do życia). Kościelna (kanoniczna) osobowość prawna wynika z chrztu świętego, przez który człowiek staje się podmiotem praw i obowiązków w Kościele właściwych chrześcijanom (np. prawo do bierzmowania).

Wśród przysługujących dziecku praw uregulowanych w KPK/83 należy przede wszystkim wskazać następujące: prawo do życia, prawo do sakramentów i prawo do wychowania.

\subsection{Prawo do życia}

Na mocy prawa naturalnego każdemu dziecku - nienarodzonemu i narodzonemu - przysługuje prawo do życia. Ustawodawca w KPK/83 gwarantuje prawo do życia zarówno dziecka poczętego, ale jeszcze nienarodzonego, jak również prawo do życia dziecka narodzonego. Z prawem do życia nierozerwalnie związane jest prawo do ochrony życia.

Osoba ludzka od momentu poczęcia posiada naturalną zdolność prawną, co oznacza, że jest podmiotem praw i obowiązków. Ustawodawca

\footnotetext{
${ }^{13}$ Dziecko - z uwagi na fakt, iż uważane jest za nieposiadające używania rozumu - co do zasady jest wolne od obowiązków. Należy jednak wskazać na pewne wyjątki występujące $\mathrm{w}$ Kodeksie. Z prawem do sakramentów świętych związane są określone obowiązki. Dziecko ma prawo być dopuszczone do Komunii świętej, ale „po uprzedniej sakramentalnej spowiedzi” (kan. 914). Ponadto „Każdy wierny, po osiągnięciu wieku rozeznania, obowiązany jest przynajmniej raz w roku wyznać wiernie wszystkie swoje grzechy ciężkie” (kan. 989). Po przyjęciu Komunii świętej po raz pierwszy dziecko nabywa obowiązek przyjmowania Najświętszej Eucharystii przynajmniej raz w roku (kan. $920 § 1$ ). Ustawodawca w KPK/83 dodaje: „Ten nakaz powinien być wypełniony w okresie wielkanocnym, chyba że dla słusznej przyczyny wypełnia się go w innym czasie w ciągu roku" (kan. $920 \S 2)$.
} 
w KPK/83 stanowi, że nasciturus posiada podmiotowość prawną ${ }^{14}$. Dlatego też fundamentalnym prawem poczętego życia ludzkiego jest prawo do życia, które podlega ochronie prawnej. Ustawodawca kodeksowy sankcjonuje przestępstwo przerwania ciąży: „Kto powoduje przerwanie ciąży, po zaistnieniu skutku, podlega ekskomunice wiążącej mocą samego prawa" (kan. 1398). Gwarantuje zatem prawo do życia, zaś jego pogwałcenie obwarował karą ekskomuniki latae sententiae wiążącej mocą samego prawa ${ }^{15}$. Ustawodawca $\mathrm{w}$ KPK/83 przypisuje życiu ludzkiemu poczętemu, ale jeszcze nienarodzonemu, takie samo prawo do życia, jak dzieciom już urodzonym ${ }^{16}$.

$\mathrm{Z}$ prawem do życia nierozłącznie związane jest uprawnienie do ochrony i obrony życia oraz zdrowia. Ustawodawca kodeksowy przyznaje matce dziecka zarówno poczętego, jak i narodzonego prawo do separacji: „Jeżeli jedno z małżonków stanowi źródło poważnego niebezpieczeństwa dla duszy lub ciała drugiej strony albo dla potomstwa, lub w inny sposób czyni zbyt trudnym życie wspólne, tym samym daje drugiej stronie zgodną z prawem przyczynę odejścia, bądź na mocy dekretu ordynariusza miejsca, bądź też gdy niebezpieczeństwo jest bezpośrednie, również własną powagą" (kan. 1153 § 1). Jako jedną z przyczyn uzasadniających separację obok zagrożenia dla współmałżonka - ustawodawca określa dobro potomstwa. Bezbronne dziecko, zwłaszcza jeszcze nienarodzone, nie ma możliwości wyegzekwować przysługującego mu prawa do ochrony i obrony życia oraz zdrowia. Dlatego też w sytuacji, w której np. żona będąc poniżana i bita przez męża z powodu ciąży, czy nawet namawiana i zmuszana do zabójstwa poczętego dziecka, dla realizacji przysługujących dziecku uprawnień ma prawo odejść od męża. Należy podkreślić, że ustawodawca w kan. 1153 § 1 gwarantuje ochronę prawną nie tylko nasciturusa, ale także dziecka narodzonego, np. w sytuacji, w której jedno z małżonków nie akceptuje choroby lub niepełnosprawności dziecka, a w konsekwencji dziecko narażone byłoby z tego tytułu na poważne niebezpieczeństwo utraty zdrowia lub życia. Ponadto, jeżeli małżonkowie zdecydują się na separację, mają obowiązek skutecznie realizować przysługujące dziecku prawo do

${ }^{14}$ Zob. także: Sitek 2017, 291-302; Słowikowska 2016, 218-26.

${ }^{15}$ Szerzej zob. Syryjczyk 2003, 175-80; Wenz 2016, 147-52.

16 „Kto popełnia zabójstwo albo siłą lub podstępem porywa lub zatrzymuje człowieka, bądź go okalecza czy poważnie rani, powinien być ukarany stosownie do ciężkości przestępstwa pozbawieniami i zakazami, o których w kan. 1336. Zabójstwo zaś osób, o których w kan. 1370, jest karane tam ustanowionymi karami” (kan. 1397). 
życia poprzez zagwarantowanie narodzenia dziecka (kan. 1154) [Korziński 2016, 22; Wenz 2016, 146-47].

\subsection{Prawo do sakramentów}

Dziecko ma prawo do chrztu. Dziecko poczęte, pomimo tego, że jeszcze nienarodzone i nieochrzczone, posiada podmiotowość prawną - tzw. naturalną zdolność prawną - na równi z każdym człowiekiem już urodzonym i nieochrzczonym [Świto 1997, 240]. Ustawodawca w KPK/83 stanowi: „Płody poronione, jeśli żyją, należy, jeśli to możliwe, chrzcić” (kan. 871). Przyznaje zatem dziecku poronionemu $-\mathrm{z}$ racji tego, że jest człowiekiem zdolność do przyjęcia chrztu, jak każdemu innemu człowiekowi już urodzonemu, który nie został jeszcze ochrzczony. W odniesieniu do dzieci narodzonych ustawodawca kodeksowy stanowi: „Rodzice mają obowiązek troszczyć się, ażeby ich dzieci zostały ochrzczone w pierwszych tygodniach; możliwie najszybciej po urodzeniu, a nawet jeszcze przed nim powinni się udać do proboszcza, by prosić o sakrament dla dziecka i odpowiednio do niego się przygotować” (kan. $867 \S 1$ ). Z obowiązkiem rodziców troski o chrzest dziecka korelatywnie związane jest uprawnienie przysługujące dziecku w tym zakresie. Ponadto w niebezpieczeństwie śmierci (in periculo mortis) dziecko powinno być natychmiast ochrzczone (kan. $867 \S 2$ ). W sytuacji niebezpieczeństwa śmierci w odniesieniu do dziecka rodziców katolickich, a nawet i niekatolickich, do godziwego udzielenia chrztu nie jest wymagana zgoda rodziców (kan. $868 \S 2$ ) $^{17}$. Ponadto ustawodawca kodeksowy stanowi, że w odniesieniu do dzieci, których rodzice mieli zamiar ochrzcić, ale zmarły przed chrztem, ordynariusz miejsca może zezwolić na pogrzeb kościelny (kan. $1183 \S 2$ ).

${ }^{17}$ Papież Franciszek znowelizował kan. $868 \S 1,2^{\circ}$ a także dodał $\S 3$ do tego kanonu, postanawiając, że do godziwego ochrzczenia dziecka wymaga się: „2 $2^{\circ}$ aby istniała uzasadniona nadzieja, że dziecko będzie wychowane po katolicku, z zachowaniem $\S 3$; jeśli jej zupełnie nie ma, chrzest należy odłożyć zgodnie z postanowieniami prawa partykularnego, powiadamiając rodziców o przyczynie”; „§ 3. Dziecko chrześcijan niekatolików jest godziwie chrzczone, jeśli o to proszą rodzice lub przynajmniej jedno $\mathrm{z}$ nich, albo ten, który ich zgodnie z prawem zastępuje, i jeśli fizycznie lub moralnie niemożliwe jest dotarcie przez nich do własnego szafarza”, zob. De concordia inter Codices, art. 4 i 5. 
Chrzest jest podstawą „nowej” podmiotowości prawnej w Kościele ${ }^{18}$. Dziecko - posiadające na mocy prawa naturalnego osobowość prawną naturalną - uzyskuje z momentem chrztu kościelną (kanoniczną) osobowość prawną. Staje się podmiotem prawa kościelnego: „Przez chrzest człowiek zostaje wcielony do Kościoła Chrystusowego i staje się w nim osobą, z obowiązkami i prawami, które - zważywszy ich pozycje - są właściwe chrześcijanom, jeśli są we wspólnocie kościelnej i o ile nie przeszkadza sankcja nałożona zgodnie z przepisem prawa” (kan. 96). Kościelna osobowość prawna nie przysługuje człowiekowi z woli ustawodawcy, nie zostaje mu ona ani nadana, ani przyznana przez prawo, ale uzyskuje ją przez chrzest, zaś prawo kanoniczne jedynie stwierdza jej nabycie i posiadanie [Zubert 2005, 563]. Przez chrzest dziecko zaciąga zobowiązania i nabywa uprawnienia właściwe chrześcijanom ${ }^{19}$. Ustawodawca kościelny stanowi, że w odniesieniu do sakramentu chrztu z dzieckiem zrównany jest ten, kto nie jest świadomy swojego działania (kan. 852 § 2).

Przysługujące dziecku od momentu chrztu prawo do sakramentów ma podstawę w kan. 213, zgodnie z którym: „Wierni [wierni chrześcijanie M.S.] mają prawo otrzymywać pomoce od swoich pasterzy z duchowych dóbr Kościoła, zwłaszcza zaś słowa Bożego i sakramentów”. W KPK/83 zostało również zagwarantowane prawo do sakramentów przysługujące dzieciom zrodzonym $\mathrm{z}$ małżeństwa mieszanego (kan. 1128) ${ }^{20}$. Ustawodawca kodeksowy przyznaje dziecku uprawnienie do przyjęcia sakramentu bierzmowania „w pobliżu wieku rozeznania”, czyli około siódmego roku życia (kan. 891) ${ }^{21}$. Dziecko ma prawo być dopuszczone do Komunii świętej,

${ }^{18}$ Chrzest uzdalnia człowieka do przyjęcia innych sakramentów: „Nikt nie może być ważnie dopuszczony do innych sakramentów, dopóki nie przyjął chrztu” (kan. $842 \S 1$ ).

${ }^{19}$ Obowiązki i prawa wszystkich wiernych chrześcijan zostały skodyfikowane w kan. 208-223, zaś wiernych świeckich w kan. 224-231.

20 „Ordynariusze miejsca oraz inni duszpasterze winni troszczyć się o to, ażeby katolickiemu małżonkowi i dzieciom zrodzonym z małżeństwa mieszanego nie zabrakło pomocy duchowej do wypełniania ich obowiązków. Mają też wspierać małżonków w utrwalaniu jedności życia małżeńskiego i rodzinnego".

${ }^{21}$ „Sakrament bierzmowania wierni powinni przyjmować w pobliżu wieku rozeznania, chyba że Konferencja Episkopatu [konferencja biskupów - M.S.] określiła inny wiek, albo istnieje niebezpieczeństwo śmierci, lub zdaniem szafarza co innego doradza poważna przyczyna” (kan. 891). Zgodnie z Pontyfikałem Rzymskim, dziecko powinno przyjąć sakrament bierzmowania około siódmego roku życia, zob. Obrzędy bierzmowania wedtug Pontyfikału Rzymskiego, Wydawnictwo Kurii Diecezjalnej, Katowice 1975, nr 11. Konferencja Episkopatu Polski wskazała: „Ze względów duszpasterskich do bierzmowania powinna przystępować młodzież, która odznacza się dojrzałością intelektualną, emocjonalną i religijną adekwatnie do swojego wieku oraz możliwości. W przygotowaniu 
jeżeli posiada „wystarczające rozeznanie” i jest dokładnie przygotowane (kan. $913 \S 1$ ). Obowiązek realizacji tego uprawnienia spoczywa przede wszystkim na proboszczu, który w szczególny sposób powinien troszczyć się o to, aby była prowadzona katecheza przygotowująca do sakramentów (kan. $777,1^{\circ}$ ), a także „aby dzieci, przez nauczanie katechetyczne trwające odpowiedni okres czasu, właściwie zostały przygotowane do pierwszego przyjęcia sakramentów pokuty i Najświętszej Eucharystii oraz do sakramentu bierzmowania" (kan. $777,2^{\circ}$ ). Dzieci mają prawo otrzymać odpowiednie i dokładne przygotowanie do sakramentów. Ponadto ustawodawca kodeksowy uprawnienie to gwarantuje także dzieciom chorym, stanowiąc, aby „katechizować także upośledzonych fizycznie i umysłowo, na ile pozwala na to ich stan" (kan. $\left.777,4^{\circ}\right)$.

\subsection{Prawo do wychowania}

Ustawodawca kodeksowy stanowi: „Rodzice mają najcięższy obowiązek i najpierwsze prawo troszczenia się zgodnie, według swoich możliwości, o wychowanie potomstwa zarówno fizyczne, społeczne i kulturalne, jak i moralne oraz religijne” (kan. 1136). Temu „najcięższemu obowiązkowi” (officium gravissimum) i „najpierwszemu prawu” (ius primarium) rodziców odpowiada uprawnienie dzieci do otrzymania wychowania na wielu płaszczyznach, tj. fizycznej, społecznej, kulturalnej, moralnej i religijnej [Pribula 2008, 561-70]. Każde dziecko ma prawo, aby już od poczęcia rozwijać się prawidłowo pod względem fizycznym i ma prawo do tego, aby się urodzić (wychowanie fizyczne); ma prawo być wychowane do czynnego udziału w życiu społecznym poprzez wyrabianie takich cnót, jak szacunek do każdego człowieka, czy miłość do ojczyzny (wychowanie społeczne); ma prawo zdobyć odpowiedni poziom rozwoju intelektualnego, dlatego powinno być posyłane do szkół, aby zapoznać się z dorobkiem ludzkości oraz kulturą duchową swojego narodu, a także rozwinąć władze umysłowe i zdolność wydawania prawidłowych sądów (wychowanie kulturalne); ma prawo do właściwego uformowania swoich dyspozycji psychicznych, dzięki którym będzie mogło świadomie regulować swoje postępowanie i zajmować

do tego sakramentu trzeba koniecznie uwzględnić możliwości osób o specjalnych potrzebach edukacyjnych (np. z niepełnosprawnością intelektualną)”, zob. Wskazania Konferencji Episkopatu Polski dotyczqce przygotowania do przyjęcia sakramentu bierzmowania (6.04.2017), http://episkopat.pl/wskazania-konferencji-episkopatu-polski-dotyczace-przy gotowania-do-przyjecia-sakramentu-bierzmowania/ [dostęp: 13.03.2018], nr 7. 
właściwe postawy (wychowanie moralne); ma prawo poznać zasady wiary i prawo żyć według tych zasad w celu uświęcenia się i osiągnięcia zbawienia (wychowanie religijne) [Pawluk 1996, 214-15; Kornecki 2014, 155-56].

Ustawodawca, wskazując na znaczenie prawa dziecka do otrzymania wychowania zwłaszcza od rodziców, przewiduje sankcję karną za niezrealizowanie tego obowiązku przez rodziców: „Rodzice lub ich zastępujący, którzy oddają dzieci do chrztu lub na wychowanie w religii niekatolickiej, powinni być ukarani cenzurą lub inną sprawiedliwą karą" (kan. 1366).

Prawu dziecka do wychowania odpowiadają także cele małżeństwa, tj. „zrodzenie i wychowanie potomstwa” (kan. $1055 \S 1$ ). Dlatego też ustawodawca kodeksowy gwarantuje dziecku prawo do wychowania również w sytuacji separacji małżonków: „Z chwilą zdecydowania o separacji małżonków, należy się zatroszczyć o odpowiednie utrzymanie i wychowanie dzieci” (kan. 1154), a także w sytuacji stwierdzenia nieważności małżeństwa: „W wyroku należy upomnieć strony o zobowiązaniach moralnych lub także cywilnych, którymi ewentualnie będą związane jedna strona względem drugiej i wobec dzieci, co do zapewnienia utrzymania i wychowania" (kan. 1689).

W odniesieniu do wychowania religijnego, ustawodawca w KPK/83 rozróżnia wychowanie chrześcijańskie (kan. 217, $226 \S 2,835 \S 4)$ i wychowanie katolickie (kan. 793-821).

\subsubsection{Prawo do wychowania chrześcijańskiego}

Przez wychowanie chrześcijańskie należy rozumieć wychowanie prowadzone w duchu religii chrześcijańskiej, dokonujące się w wymiarze strukturalnym w ramach trzech zasadniczych wyznań chrześcijańskich: katolickiego, prawosławnego i protestanckiego [Sieroń 2007, 69; Sitarz 2017, 63-86].

Ustawodawca w KPK/83 w zakresie prawa do wychowania chrześcijańskiego stanowi: „Wierni, którzy przez chrzest są powołani do prowadzenia życia zgodnego z doktryną ewangeliczną, posiadają prawo do wychowania chrześcijańskiego, przez które mają być odpowiednio przygotowani do osiągnięcia dojrzałości osoby ludzkiej i jednocześnie do poznania i przeżywania tajemnicy zbawienia" (kan. 217). Dziecko powinno otrzymać chrześcijańskie wychowanie zgodnie z nauką przekazywaną przez Kościół w pierwszej kolejności od rodziców. „Rodzice, ponieważ dali dzieciom życie, mają bardzo poważny obowiązek i prawo ich wychowania. Stąd też na pierwszym miejscu do chrześcijańskich rodziców należy troska o chrześcijańskie wycho- 
wanie dzieci, zgodnie z nauką przekazywaną przez Kościół” (kan. 226 § 2). Rodzice uczestniczą $\mathrm{w}$ munus sanctificandi w szczególny sposób poprzez chrześcijańskie wychowanie swoich dzieci (kan. $835 \S 4)^{22}$. Ustawodawca kodeksowy stanowi: „Rodzice przed innymi mają obowiązek słowem i przykładem formować dzieci w wierze i praktyce życia chrześcijańskiego. Podobny obowiązek spoczywa na tych, którzy zastępują rodziców oraz na chrzestnych" (kan. $774 \S 2$ ). Dziecko ma prawo otrzymać formację duchową od rodziców, opiekunów oraz chrzestnych potwierdzoną praktyką życia chrześcijańskiego. W realizacji prawa dziecka do wychowania chrześcijańskiego, rodziców powinny wspierać również inne podmioty, takie jak Kościół i państwo.

\subsubsection{Prawo do wychowania katolickiego}

Wychowanie katolickie, które jest pojęciem węższym niż wychowanie chrześcijańskie, stanowi konkretyzację wychowania chrześcijańskiego według zasad Kościoła Katolickiego i dokonuje się pod zwierzchnictwem władzy kościelnej [Wolicki 2008, 101]. Ma podstawę w duchu wartości chrześcijańskich i Magisterium Kościoła.

Prawo dziecka do otrzymania katolickiego wychowania wynika przede wszystkim z kan. 793-995 skodyfikowanych w Księdze III KPK/83 w Tytule III „Wychowanie katolickie”. Dzieciom przysługuje uprawnienie do wychowania katolickiego ze strony rodziców oraz tych, którzy ich zastępują. Ustawodawca stanowi: „Rodzice oraz ci, którzy ich zastępują, mają obowiązek i zarazem prawo dobrania takich środków i instytucji, przy pomocy których, uwzględniając miejscowe warunki, mogliby lepiej zadbać o katolickie wychowanie swoich dzieci (kan. 793 § 1)”. W sposób szczególny troska o katolickie wychowanie dzieci spoczywa na proboszczu (kan. $528 \S 1,776$ ).

Podobnie, jak przy realizacji prawa dzieci do wychowania chrześcijańskiego, w wychowaniu katolickim rodziców wspierają instytucje kościelne (kan. 794) ${ }^{23}$ i państwowe (kan. $\left.793 \S 2\right)^{24}$. Wychowanie katolickie powinno

\footnotetext{
${ }^{22}$ „W zadaniu uświęcania mają swój własny udział również pozostali wierni, uczestnicząc czynnie na swój sposób w nabożeństwach liturgicznych, zwłaszcza w Eucharystii. W szczególny sposób uczestniczą w tej posłudze rodzice, prowadząc w duchu chrześcijańskim życie małżeńskie i podejmując chrześcijańskie wychowanie dzieci (kan. $835 \S 4)$ ".

23 „§ 1. Z szczególnej racji prawo i obowiązek wychowania należy do Kościoła, któremu została zlecona przez Boga misja niesienia ludziom pomocy, aby mogli osiągnąć pełnię
} 
objąć pełną formację osoby ludzkiej, „dlatego dzieci i młodzież tak winny być wychowywane, ażeby harmonijnie mogły rozwijać swoje przymioty fizyczne, moralne oraz intelektualne, zdobywać coraz doskonalszy zmysł odpowiedzialności, właściwie korzystać z wolności i przygotowywać się do czynnego udziału w życiu społecznym" (kan. 795$)^{25}$.

\section{WNIOSKI}

Z przeprowadzonej analizy praw dziecka zagwarantowanych w KPK/83 można wyciągnąć następujące wnioski:

1) Pod pojęciem „dziecko” należy rozumieć osobę fizyczną od poczęcia do ukończenia 7. roku życia. Dziecko w KPK/83 uważane jest za nieposiadające używania rozumu i niezdolne do kierowania swoim postępowaniem, nie podlega ustawom kościelnym. Ma zdolność prawną, ale nie posiada zdolności do czynności prawnych, stąd w wykonywaniu swoich uprawnień podlega władzy rodziców lub opiekunów.

2) Dziecko od poczęcia posiada naturalną osobowość prawną, natomiast z momentem chrztu uzyskuje kościelną (kanoniczną) osobowość prawną. Zostaje włączone do Kościoła stając się podmiotem praw i obowiązków właściwych wiernym chrześcijanom. Dlatego też twierdzenie, że dziecku poczętemu również przysługują określone uprawnienia, ma podstawę w naturalnej podmiotowości prawnej.

3) Dziecku od momentu poczęcia przysługuje prawo do życia. Ochrona tego prawa zagwarantowana została przez ustawodawcę kodeksowego przede wszystkim poprzez obwarowanie karą ekskomuniki latae sententiae przestępstwa tzw. „przerwania ciąży”.

4) Dziecko ma prawo do duchowych dóbr Kościoła, zwłaszcza do sakramentów. Ustawodawca kościelny wyraża szczególną troskę w zakresie chrztu świętego, który uzdalnia człowieka do przyjęcia innych sakramentów.

\footnotetext{
życia chrześcijańskiego. $§ 2$. Do duszpasterzy należy obowiązek czynić wszystko, ażeby wszyscy wierni mogli otrzymać katolickie wychowanie” (kan. 794).

${ }^{24}$ „Rodzice mają również prawo otrzymania od państwa pomocy potrzebnych do katolickiego wychowania dzieci” (kan. $793 \S 2$ ).

${ }^{25}$ Szerzej na temat podstaw teologicznych i prawnych wychowania chrześcijańskiego i katolickiego zob. Sitarz 2016, 196-204.
} 
5) Każde dziecko ma prawo do wychowania fizycznego, społecznego, kulturalnego, moralnego i religijnego. Obowiązek wychowania spoczywa zwłaszcza na rodzicach. Nie wystarczy bowiem zrodzić dziecka, ale należy je także wychować. Dziecku zostało zagwarantowane w KPK/83 prawo do wychowania zarówno chrześcijańskiego, jak i katolickiego.

\section{PIŚMIENNICTWO}

Kornecki, Tomasz. 2014. „Prawa i obowiązki wiernych ze szczególnym uwzględnieniem praw i obowiązków rodziny." Annales Canonici 10:151-62.

Korziński, Ireneusz. 2016. „Podmiotowość prawna dziecka nienarodzonego.” Rocznik Teologii Katolickiej 15, nr 1:15-25. doi: 10.15290/rtk.2016.15.1.03

Pawluk, Tadeusz. 1996. Prawo kanoniczne wedtug Kodeksu Jana Pawła II. T. 2, Prawo matżeńskie. Olsztyn: Warmińskie Wydawnictwo Diecezjalne.

Pawluk, Tadeusz. 2002. Prawo kanoniczne według Kodeksu Jana Pawła II. T. 1, Zagadnienia wstępne $i$ normy ogólne. Olsztyn: Warmińskie Wydawnictwo Diecezjalne.

Plezia, Marian, red. 2007. Stownik tacińsko-polski. T. 3. Warszawa: Wydawnictwo Naukowe PWN.

Pribula, Marek. 2008. „Prawo do wychowania fundamentalnym prawem dziecka.” W Dziecko. Studium interdyscyplinarne, red. Ewa Sowińska, Elżbieta Szczurko, Tadeusz Guz, i Paweł Marzec, 561-70. Lublin: Wydawnictwo KUL.

Romanko, Agnieszka. 2017. "Amendments to Prescripts Concerning Ecclesiastical Enrollment in Motu Proprio De Concordia inter Codices Issued by Pope Francis." In The Enrollment to the Catholic Church, ed. Stanisław Kawa, Agnieszka Romanko, Mirosław Sitarz, and Anna Słowikowska, 133-54. Roma: Libreria Editrice Vaticana.

Rybczyk, Józef. 1983. „Dziecko. V. Status prawny. A. W prawie kanonicznym. W Encyklopedia Katolicka, t. 4, red. Romuald Łukaszyk, Ludomir Bieńkowski, i Feliks Gryglewicz, 565-66. Lublin: Towarzystwo Naukowe KUL.

Sieroń, Roman Bogusław. 2007. Model wychowania chrześcijańskiego wedtug św. Pawta Apostoła. Sandomierz: Wydawnictwo Diecezjalne i Drukarnia w Sandomierzu.

Sitarz, Mirosław. 2004. Stownik prawa kanonicznego. Warszawa: Instytut Wydawniczy Pax.

Sitarz, Mirosław. 2016. „Theological and legal foundations of Christian and Catholic education.” Teka Komisji Prawniczej. Polska Akademia Nauk Oddziat w Lublinie 9:196-204.

Sitarz, Mirosław. 2017. „Ochrona funkcji wychowawczej rodziny w prawie kanonicznym." W Matżeństwo i rodzina $w$ prawie kanonicznym $i w$ prawie polskim, red. Józef Krukowski, Mirosław Sitarz, i Janusz Gręźlikowski, 63-86. Lublin: Towarzystwo Naukowe KUL.

Sitek, Magdalena. 2017. „Prawa nasciturusa przeciwko prawu kobiety do aborcji. Konflikt między aksjologią a przepisami prawa.” W Nasciturus pro iam nato 
habetur. O ochronę dziecka poczętego i jego matki, red. Jacek Mazurkiewicz, i Piotr Mysiak, 291-302. Wrocław: [brak informacji o Wydawnictwie].

Słowikowska, Anna. 2016. „After-birth abortion - critical analysis of the legal aspekt." Teka Komisji Prawniczej. Polska Akademia Nauk Oddziat w Lublinie 9:218-26.

Sobański, Remigiusz. 2003. „Pozycja kanoniczna osób fizycznych. W Komentarz do Kodeksu Prawa Kanonicznego. T. I: Księga I. Normy ogólne, red. Józef Krukowski, 164-86. Poznań: Pallottinum.

Syryjczyk, Jerzy. 2003. Kanoniczne prawo karne. Część szczególna. Warszawa: Wydawnictwo UKSW.

Świto, Lucjan. 1997. „Osobowość prawna nasciturusa w prawie kanonicznym i polskim.” Prawo Kanoniczne 40, nr 1-2:233-48.

Walesa, Czesław. 1983. „Dziecko.” W Encyklopedia Katolicka, t. 4, red. Romuald Łukaszyk, Ludomir Bieńkowski, i Feliks Gryglewicz, 501-502. Lublin: Towarzystwo Naukowe KUL.

Wenz, Wiesław. 2016. „Ochrona życia dziecka poczętego w prawie kanonicznym.” Kościót i Prawo 5 (18), nr 2:127-65. doi: 10.18290/kip.2016.5.2-8

Wiak, Krzysztof. 2017. „Pojęcie 'dziecko' w Kodeksie karnym na tle wzorców międzynarodowych i konstytucyjnych.” Teka Komisji Prawniczej. Polska Akademia Nauk Oddziat w Lublinie 9:261-73.

Wolicki, Marian. 2008. „Wychowanie katolickie a wychowanie chrześcijańskie.” Pedagogika Katolicka 2:99-105.

Zubert, Bronisław Wenanty. 2005. „Chrzest - podstawą nowej podmiotowości prawnej”, w: Bronisław Wenanty Zubert OFM. Pro iure et vita. Wybór pism, red. Elżbieta Szczot, 559-71. Lublin: Wydawnictwo KUL.

\section{Prawa dziecka w Kodeksie Prawa Kanonicznego z 1983 roku. Wybrane zagadnienia}

\section{Streszczenie}

Zgodnie z Kodeksem Prawa Kanonicznego z 1983 r. dzieckiem nazywa się małoletniego przed ukończeniem siódmego roku życia i uważane jest za nieposiadające używania rozumu. Uprawnienia przysługujące dziecku mają podstawę zarówno w naturalnej osobowości prawnej, jak i w kościelnej osobowości prawnej. Ustawodawca w Kodeksie Prawa Kanonicznego z 1983 r. reguluje m.in. następujące prawa dziecka: prawo do życia, prawo do sakramentów, prawo do wychowania.

Słowa kluczowe: osobowość prawna; prawo do życia; prawo do sakramentów; prawo do wychowania 


\section{The Rights of the Child in the 1983 Code of Canon Law.} Selected Issues

\section{Sum m a ry}

According to the 1983 Code of Canon Law the child is a minor before the completion of the seventh year, who is considered not to be responsible for itself. The rights of the child stem both from natural legal personality and church legal personality. The 1983 Code legislator regulates rights of the child such as: the right to life, right to the sacraments and right to upbringing.

Key words: legal personality; right to life; right to the sacraments; right to upbringing

Information about Author: Rev. MirosŁaW Sitarz, HaB. J.C.D., University Professor - Head of the Department of Public and Constitutional Church Law, Institute of Canon Law, Faculty of Law, Canon Law and Administration at the John Paul II Catholic University of Lublin; Al. Racławickie 14, 20-950 Lublin, Poland; e-mail: mpsitarz@kul.pl; https://orcid.org/0000-0001-7596-8508 